\title{
ВИВЧЕННЯ АДАПТАЦІЙНИХ МЕХАНІЗМІВ ПРИ КОМПРЕСІЇ ПЛЕЧА МАНЖЕТОЮ
}

\author{
Д. В. Вакуленко, Л. О. Вакуленко, О. В. Кутакова ${ }^{1}$ \\ ДВНЗ «Тернопільський державний медичний університет \\ імені І. Я. Горбачевського МОЗ України» \\ ${ }^{1}$ Комунальна установа «Центральна районна лікарня» Житомирської районної ради
}

\begin{abstract}
Вивчено адаптаційні механізми організму щодо компресії плеча манжетою. Компресія плеча під час вимірювання артеріального тиску сприймається організмом як навантаження. Адаптація організму до компресії плеча у молодих людей (віком 18-20 років) супроводжується підвищенням активності перифрерійного (автономного), вегетативного, гіпоталамо-гіпофрізарного рівнів регуляції діяльності серцево-судинної системи. Активність центральної нервової системи при цьому не зростає. Продовження досліджень із застосуванням часового та спектрального аналізу електрокардіограми в різних інтервалах дасть можливість в подальшому використовувати отриману інформацію для вивчення адаптаційної здатності окремих ділянок міокарда під час компресії плеча та під впливом інших фракторів.
\end{abstract}

Ключові слова: ЕКГ, вимірювання артеріального тиску, компресія плеча манжетою, адаптаційні механізми.

\section{ИЗУЧЕНИЕ АДАПТАЦИОННЫХ МЕХАНИЗМОВ ПРИ КОМПРЕССИИ ПЛЕЧА МАНЖЕТОЙ}

\author{
Д. В. Вакуленко, Л. О. Вакуленко, О. В. Кутакова ${ }^{1}$ \\ ДВНЗ «Тернопольский государственный медицинский университет \\ имени И Я. Горбачевского МОЗ Украины» \\ ${ }^{1}$ Коммунальное учреждение «Центральная районная больница» \\ Житомирского районного совета
}

\begin{abstract}
Изучено адаптационные механизмы организма в отношении компрессии плеча манжетой. Компрессия плеча во время измерения артериального давления воспринимается организмом как нагрузка. Адаптация организма к компрессии плеча у молодых людей (возраст 18-20 лет) сопровождается повышением активности перисрерического (автономного), вегетативного, гипоталамо-гипофизарного уровней регуляции деятельностью сердечно-сосудистой системы. Активность центральной нервной системы при этом не возрастает. Продолжение исследований с применением временного и спектрального анализа электрокардиограммы в различных интервалах позволит в дальнейшем использовать полученную инорормацию для изучения адаптационной способности отдельных участков миокарда во время компрессии плеча и под влиянием других фракторов.
\end{abstract}

Ключевые слова: ЭКГ, измерение артериального давления, компрессия плеча манжетой, адаптационные механизмы. 


\title{
STUDY OF COMPRESSION ADAPTATION MECHANISMS TO SHOULDER CUFFS
}

\author{
D. V. Vakulenko, L. O. Vakulenko, O. V. Kutakova ${ }^{1}$ \\ I. Ya. Horbachevsky Ternopil Medical State University of Ministry of Health of Ukraine \\ ${ }^{1}$ Municipal institution «Central District Hospital» Zhytomyr District Council
}

\begin{abstract}
It were studied the adaptive mechanisms of the organism to compression of shoulder with cuff. Shoulder compression during blood pressure measurements perceived by the body as stress. The adaptation of the body to the shoulder compression in young adults (18-20 years old) accompanied by an increased activity of peripheral, autonomic, hypothalamic-pituitary level of regulation of the cardiovascular system; but the activity of the central nervous system do not increasing. Extension studies using time and spectral analysis of ECG in various intervals will make it possible to re-use the obtained data to study the adaptive capacity of individual sections of the myocardium during compression of shoulder and under the influence of other factors.
\end{abstract}

Key words: ECG, blood pressure measurement, compression of shoulder with cuff, adaptive mechanisms.

Вступ. Серцево-судинні захворювання (СС3) основна причина смертності у всьому світі. За даними ВООЗ щорічно від ССЗ помирають близько 17,5 млн. людей. При цьому, 80 \% критичних станів, таких як інфаркт міокарда та інсульт, можна було попередити. Підвищений артеріальний тиск - основний фактор ризику розвитку серцевосудинних катастроф. Число хворих на артеріальну гіпертензію у світі становить близько 20-30 \% населення.

Вимірювання артеріального тиску - основний метод виявлення хворих з артеріальною гіпертензію та є обов'язковою складовою обстеження кожного пацієнта. Компресію плеча манжетою при цьому потрібно розглядати як навантаження на організм людини. Відбувається перерозподіл кровотоку в організмі, виникає больовий стрес, з перетисненої манжеткою та з розміщених дистальніше від місця стискання ділянок кінцівки поступають сигнали від різноманітних рецепторів про відсутність кровотоку, обміну киснем, поживними речовинами тощо [1]. Реакція серцево-судинної системи на компресію свідчить про рівень адаптаційних можливостей організму, стан координації між місцевими саморегуляторними механізмами та центральною нейрогуморальною регуляцією [2]. Вивчення процесів, які відбуваються в організмі під час вимірювання артеріального тиску, розширює та поглиблює інформаційні можливості дослідження стану серцево-судинної системи як індикатора адаптаційних реакцій цілісного організму.

Мета роботи: вивчити вплив компресії плеча манжетою на діяльність серцево-судинної системи за допомогою математичного аналізу варіабельності серцевого ритму на підставі електрокардіограми
(ЕКГ), зареєстрованої до та під час вимірювання артеріального тиску; дослідити механізми, задіяні в процесі адаптації до компресії плеча манжетою.

Матеріали та методи дослідження. Нами обстежено 55 молодих людей віком 18-20 років, без скарг на стан здоров’я. Проведено реєстрацію ЕКГ в першому стандартному відведенні до та під час вимірювання артеріального тиску. Для вивчення адаптаційної здатності вегетативної (автономної) нервової системи (ВНС) до компресії плеча манжетою проводили аналіз варіабельності серцевого ритму за часовими [1, 2] та спектральними [2, 3] показниками. Вивченню підлягали розраховані показники інтервалів RR, PP, TT. Аналіз записів ЕКГ проводили в розробленій авторами програмі аналізу ЕКГ, артеріальних осцилограм, реограм та пульсограм [2]. Вказана програма дає можливість аналізувати біосигнали за часовим, спектральним, фрактальним, кореляційним, кластерним та статистичними методами аналізу, також проводити розрахунок різних співвідношень інтервалів.

Результати та їх обговорення. Часовий аналіз. Як оцінювані показники були обрані основні показники варіабельності серцевого ритму: частота серцевих скорочень, SDNN, RMSSD, Mо, AMо, pNN50, HVR-index, VR, VPR. Представляємо результати динаміки трьох останніх (рис. 1). Під час вимірювання артеріального тиску отримано достовірне зниження HVR-index - триангулярного індексу, VPR - вегетативного показника ритму, VR - варіаційного розмаху.

Зниження триангулярного індексу (р < 0,001), може вказувати на посилений вплив симпатичної ланки ВНС і вище розташованих центрів регуляції серцевого ритму, реакцію нейрогуморальної систе- 


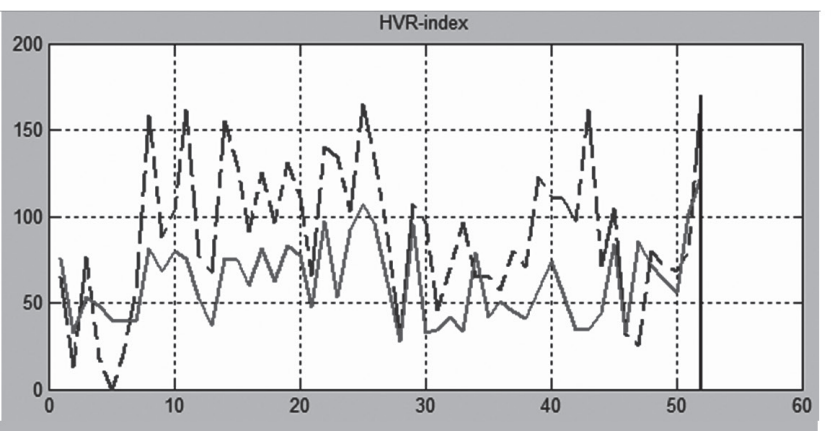

a)

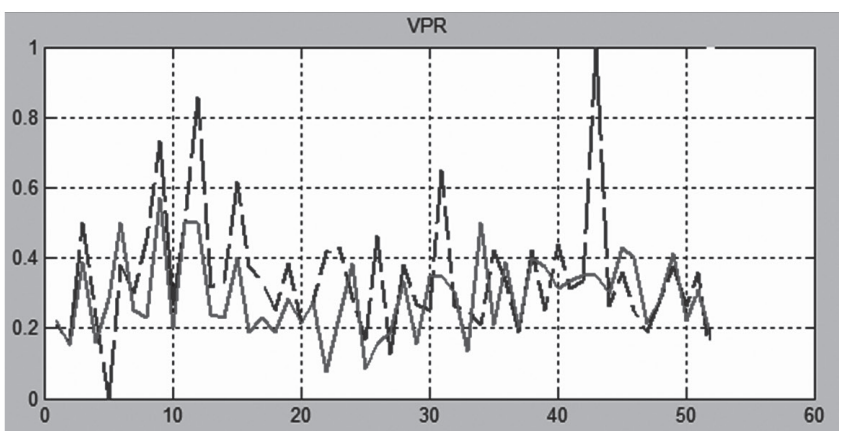

б)

Рис. 1. Динаміка значень: а) триангулярного індексу (HVR-index), б) вегетативного показника ритму (VPR) EKГ до (переривчаста лінія) та під час (суцільна лінія) компресії плеча при вимірюванні артеріального тиску (55 осіб, вік 19-20 років)

ми, а також збільшення регулярності ритму. Зменшення варіаційного розмаху ( $<0,001)$ свідчить про активацію симпатичної ланки. Достовірність указаних показників підтверджується їх односпрямованою динамікою, бо вважається, що вони еквівалентні. Зниження вегетативного показника ритму (р $<0,05)$ вказує на активацію центральних механізмів регуляції та зниження впливу парасимптаичної ланки (вагусу) на синусовий вузол.

Спектральний аналіз. Для аналізу ритмограми застосували швидке перетворення Фур'є в діапазоні спектру від 0,003 Гц до 0,4 Гц. Він формується чотирма видами хвиль різного походження: HFint, LFint, VLFint та ULFint. Спектральний аналіз дозволяє розкласти ритмограмму на складові її хвилі і кількісно оцінити вклад кожної з них [4].

Спектральний аналіз серед 55 досліджуваних, що не мали скарги на здоров'я засвідчив, що вимірювання артеріального тиску викликає напруження адаптаційних механізмів, сприяє підвищенню потужності спектру LFint (низьких) i VLFint (наднизьких) та HFint (швидких) хвиль в загальному спектрі (рис. 2 а, б, в).

Значення потужності сектру HFint (рис. 3 в) хвилі високої частоти $(0,15-0,4$ Гц) - достовірно збільшувалось ( $<0,001)$, що вказує на зростання активності парасимпатичного кардіоінгібіторного центру довгастого мозку, що реалізуються через блукаючий нерв під впливом компресії плеча.

LFint - потужність хвиль $(0,04-0,15$ Гц) низької частоти, відображає активність симпатичних центрів довгастого мозку (кардіостимулючого та вазоконстрикторного), систему регуляції судинного тонусу. Реалізуються через вплив симпатичної і парасимпатичної систем, але переважно за рахунок імпульсів від верхнього грудного симпатичного ганглія. Достовірне (p < 0,001) збільшення LFint під час вимірювання артеріального тиску свідчить про активацію симпатичної ланки ВНС.

VLFint (0,003-0,04 Гц) - повільні хвилі другого порядку, дуже низькочастотні хвилі - відображають активність центральних ерготропних і гуморально-метаболічних механізмів регуляції серцевого ритму. Реалізується через зміни вмісту в крові гормонів (ренін, ангіотензин, альдостерон тощо).

Дослідження показують, що вимірювання артеріального тиску сприймається організмом як навантаження. Це проявляється збільшенням спектру повільних і дуже повільних хвиль, що вкаузє на активацію симпатичної ланки вегетативної нервової системи та зростання рівня централізації системи кровообігу. При цьому залучаються вищі рівні регуляції, задіюючи центральну ланку за рахунок активації гуморально-метаболічних механізмів. Підвищення потужності хвиль високої частоти під час вимірювання аретріального тиску вказує на підвищення адаптативних механізмів організму обстежених за рахунок активації парасимпатичної системи.

Загальна потужність спектру ВСР Totalint (рис. 2 г) - абсолютний рівень активності регуляторних систем (діапазон частот $\leq 0,4$ Гц), що відображає вплив симпатичного та парасимпатичного відділів автономної системи, сумарний ефект впливу на серцевий ритм усіх рівнів регуляції. Цей показник характеризує періодичні процеси в ритмі серця. Зростання Totalint дозволяє судити про підвищення загальної потужності, вказує на активацію симпатичного відділу автономної нервової системи. При навантаженні на організм спостерігається збільшення частоти серцевих скорочень і загальної потужності спектру зі зростанням відносної долі низькочастотних компонентів. Між вегетативними симпатичними і гуморальними контурами, як i 


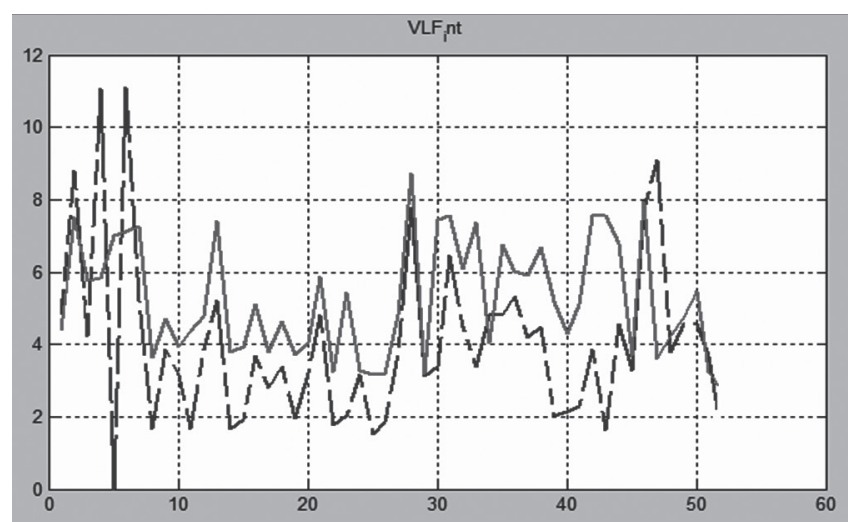

a)



B)

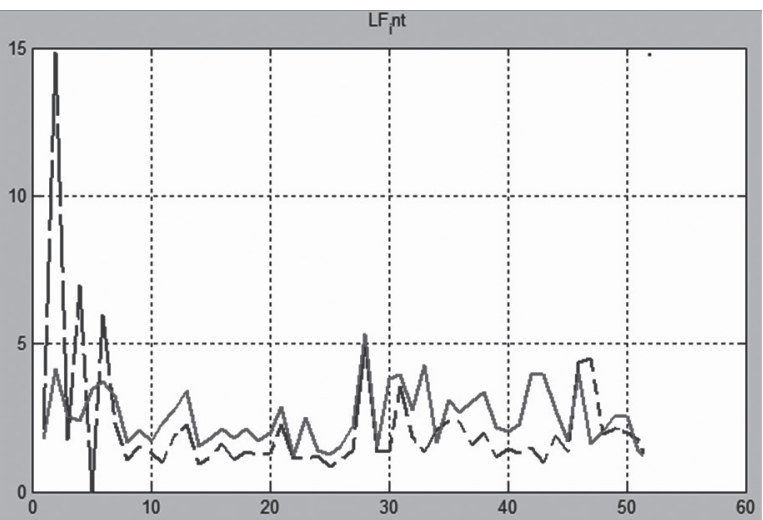

б)

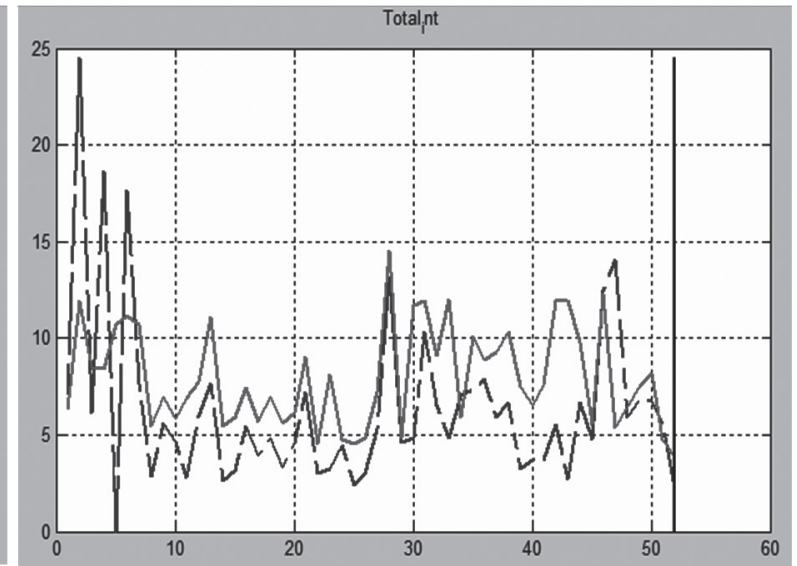

Г)

Рис. 2. Динаміка потужності спектру: а) VLFint, б) LFint, в) HFint, г) Totalint визначений у 55 обстежених до (переривчаста лінія) та під час (суцільна лінія) компресії плеча

між вегетативними парасимпатичними і симпатичними, в живому організмі чіткої межі провести неможливо. В цілісному контурі регуляції всі його складові діють як єдиний ансамбль, i організм реагує на вплив (зовнішній, внутрішній стрес будь-якої природи і інтенсивності) як цілісна система [1]. Отже, при вимірюванні артеріального тиску у молодих людей 18-20 років підвищення загальної потужності спектру свідчить про високі адаптаційні можливості організму.

Хвилі мозкової активності. Здійснення ритмічної активності серця можливе лише при існуванні певних фазових співвідношень між коливальними мозковими і серцевими процесами. Найбільш важливий аспект, що зв’язує хвилі мозкової активності зі здоров’ям людини - здатність змінювати ці стани у відповідності з вимогами ситуації [3]. Система управління цими ритмами функціонально і морфологічно входить у склад єдиної адаптаційної вертикалі, що забезпечує перебіг адаптаційних реакцій до умов зовнішнього та внутрішнього середовища [1].
При аналізі електрокардіограм з метою моніторингу біоелектричної активності мозку застосували спектральний аналіз ЕКГ. Для визначення потужності спектру мозгової активності використано перетворення Фур’є, для потужність миттєвої частоти - Гільберта - Хуанга до самого сигналу, а не інтервалограми [2, 3].

Ритми хвиль активності мозку діляться залежно від їх частот (бета, альфа, тета, дельта). Указані показники визначали до вимірювання артеріального тиску та під час компресії плеча. За перетворенням Фур’є достовірне зменшення ( $<0,05)$ спостерігалось лише для потужності спектру альфа. В інших діапазонах мозкової активності достовірні зміни були відсутні. Активність альфа (9-13 Гц) хвиль проявляється в період сенсорого спокою, розумової релаксації, медитації. Зменшення потужності спектру вказаного діапазону (за відсутності динаміки з боку інших частот) може бути свідченням характеру мобілізації мозкової активності до компресії плеча.

В той же час при вивченні потужності миттєвої частоти, розрахованої за перетворенням Гільберта- 
Таблиия 1

Показники потужності спектру мозкової активності до та під час компресії плеча манжетою

\begin{tabular}{|c|c|c|c|c|c|}
\hline \multirow{2}{*}{ Показник } & \multicolumn{2}{|c|}{ до компресії } & \multicolumn{3}{c|}{ з компресією } \\
\cline { 2 - 6 } & $\mathrm{M}$ & $\mathrm{m}$ & $\mathrm{M}$ & $\mathrm{m}$ & $\mathrm{p}$ \\
\hline Alpha & 0,784 & 0,252 & 0,691 & 0,230 & $<0,05$ \\
\hline DeltaH & 0,015 & 0,001 & 0,012 & 0,001 & $<0,05$ \\
\hline TetaH & 0,046 & 0,002 & 0,036 & 0,002 & $<0,05$ \\
\hline AlphaH & 0,096 & 0,004 & 0,072 & 0,004 & $<0,05$ \\
\hline BetaH & 0,295 & 0,013 & 0,215 & 0,012 & $<0,05$ \\
\hline
\end{tabular}

Примітка. Показники з індексом Н відображають потужності миттєвої частоти, розрахованої за перетворенням Гільберта Хуанга (DeltaH, TetaH, AlphaH, BetaH), а без вказаного індексу - потужність спектру за перетворенням Фур’є (Alpha)



a)

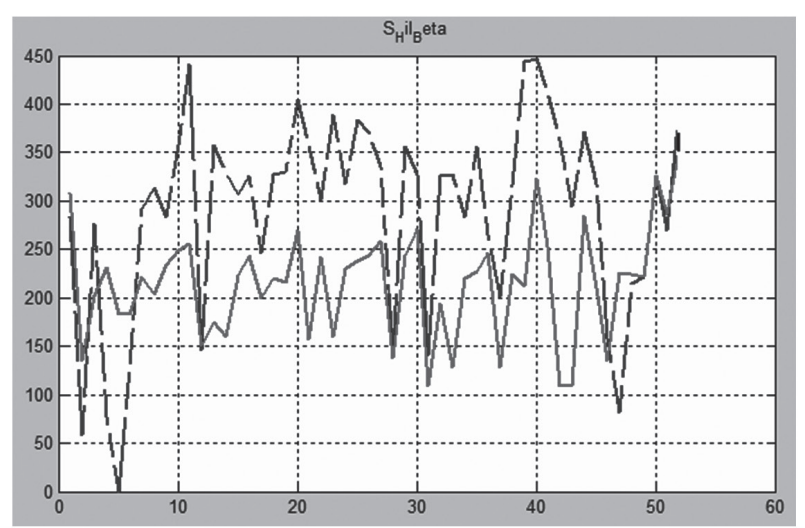

B)

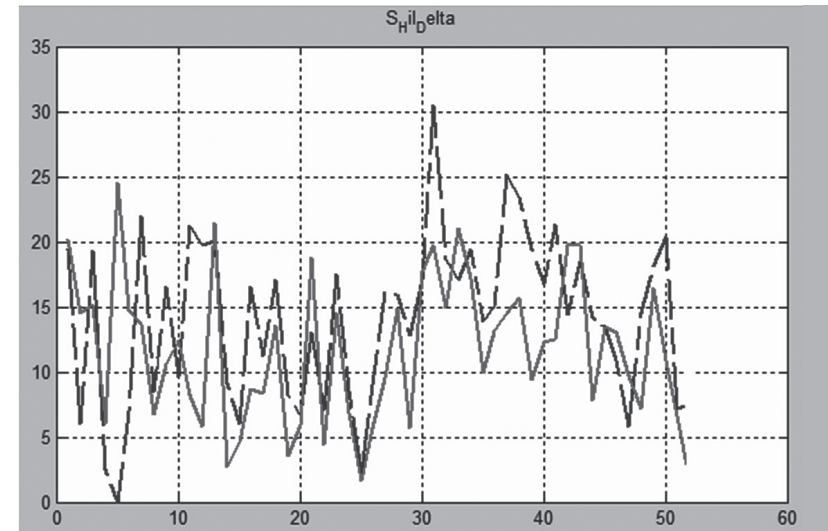

б)

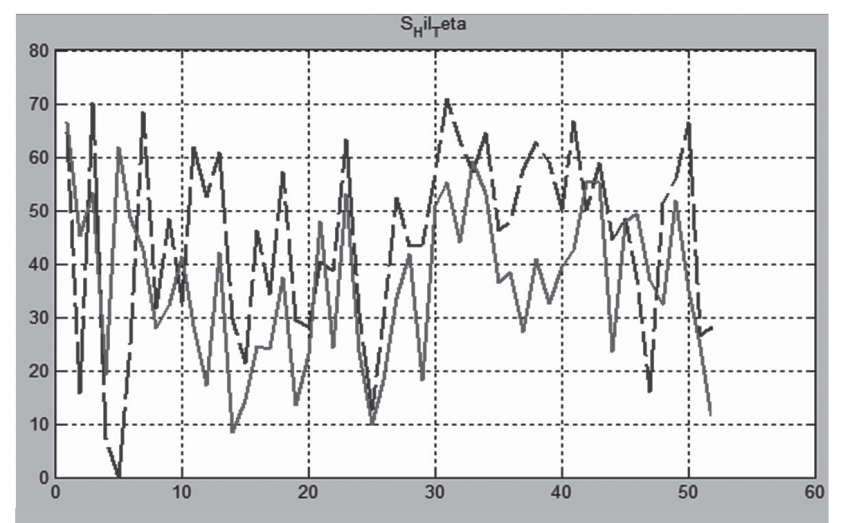

г)

Рис. 3. Динаміка показників миттєвої фази за перетворенням Гільберта -Хуанга: а) альфа-хвиль,

б) бета-хвиль, в) дельта-хвиль, г) тета-хвиль до (переривчаста лінія) та під час (суцільна лінія) 
Показники часового, спектрального частотного аналізу інтервалів RR, PP та TT до та під час компресії плеча манжетою

\begin{tabular}{|c|c|c|c|c|c|c|c|c|c|c|c|c|c|c|c|}
\hline \multirow{4}{*}{  } & \multicolumn{15}{|c|}{ Досліджуваний інтервал } \\
\hline & \multicolumn{5}{|c|}{$\mathrm{RR}$} & \multicolumn{5}{|c|}{ PP } & \multicolumn{5}{|c|}{ TT } \\
\hline & \multicolumn{2}{|c|}{$\begin{array}{c}\text { до } \\
\text { компресії }\end{array}$} & \multicolumn{3}{|c|}{ з компресією } & \multicolumn{2}{|c|}{$\begin{array}{c}\text { до } \\
\text { компресії }\end{array}$} & \multicolumn{3}{|c|}{ з компресією } & \multicolumn{2}{|c|}{$\begin{array}{c}\text { до } \\
\text { компресії }\end{array}$} & \multicolumn{3}{|c|}{3 компресією } \\
\hline & M & $\mathrm{m}$ & $\mathrm{M}$ & $\mathrm{m}$ & p & $\mathrm{M}$ & $\mathrm{m}$ & $\mathrm{M}$ & $\mathrm{m}$ & $\mathrm{p}$ & M & $\mathrm{m}$ & M & $\mathrm{m}$ & p \\
\hline BP & 0,27 & 0,02 & 0,25 & 0,02 & $<0,05$ & 0,311 & 0,019 & 0,275 & $\mid 0,016$ & $<0,05$ & 0,348 & 0,025 & 0,339 & 0,027 & $>0,4$ \\
\hline VPR & 0,35 & 0,02 & 0,29 & 0,02 & $<0,02$ & 0,399 & 0,029 & 0,328 & $\mid 0,017$ & $<0,01$ & 0,446 & 0,033 & 0,406 & 0,033 & $>0,15$ \\
\hline HVR & 90,7 & 5,7 & 62,2 & 4,9 & $<0,001$ & 89,2 & 5,7 & 61,1 & 3,2 & $<0,001$ & 88,3 & 3,6 & 60,0 & 2,2 & $<0,001$ \\
\hline $\mathrm{VLF}_{\text {int }}$ & 4,120 & 0,317 & 5,259 & 0,297 & $<0,001$ & 4,234 & 0,332 & 5,367 & 0,234 & $<0,001$ & 4,323 & 0,344 & 5,410 & 0,232 & $<0,001$ \\
\hline $\mathrm{LF}_{\text {int }}$ & 2,218 & 0,307 & 2,515 & 0,239 & $<0,001$ & 2,235 & 0,303 & 2,547 & 0,136 & $<0,001$ & 2,286 & 0,297 & 2,680 & 0,155 & $<0,001$ \\
\hline $\mathrm{HF}_{\mathrm{int}}$ & 0,186 & 0,021 & 0,219 & 0,019 & $<0,001$ & 0,198 & 0,023 & 0,228 & 0,012 & $<0,001$ & 0,211 & 0,027 & 0,246 & 0,015 & $<0,001$ \\
\hline Total $_{\text {int }}$ & 6,523 & 0,607 & 7,993 & 0,527 & $<0,05$ & 6,667 & 0,622 & 8,141 & 0,379 & $<0,05$ & 6,820 & 0,644 & 8,337 & 0,396 & $<0,05$ \\
\hline
\end{tabular}

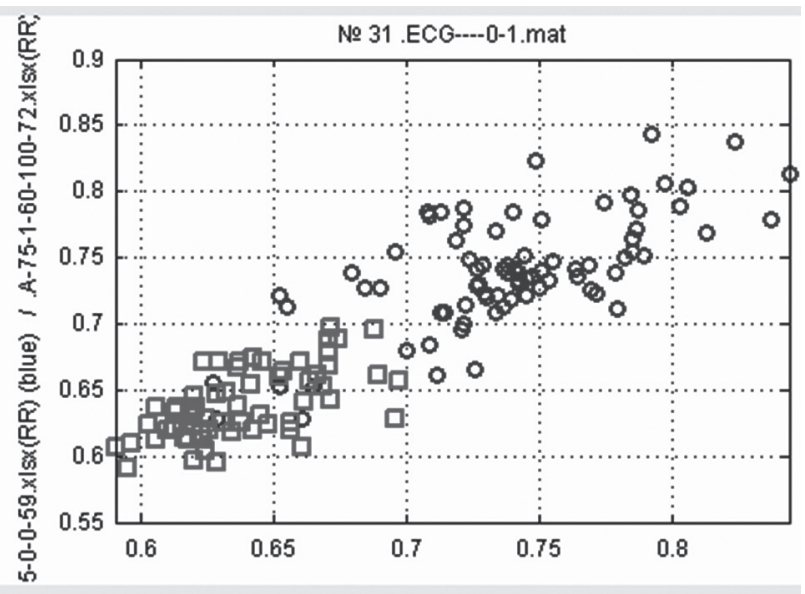

Рис. 4. Скатерограма юнака Р., 18 років

(притаманна для усієї досліджуваної вибірки), отримана за аналізом інтервалів RR EKГ, зареєстрованої до (круглі) та під час (квадратні відмітки) компресії плеча

Хуанга (від 0 Гц до 3 кГц), ми отримали ії достовірне зменшення в діапазонах альфа, бета, тета, дельта ( $<$ 0,001), що може свідчити про рівень миттєвих процесів мозкової активності (табл. 1, рис. 3).

Як видно з табл. 1 та рис. 3, при вимірюванні артеріального тиску у 55 осіб за результатами аналізу ЕКГ спостерігалась участь мозкових процесів в адаптації до компресії плеча. Слід відмітити, що

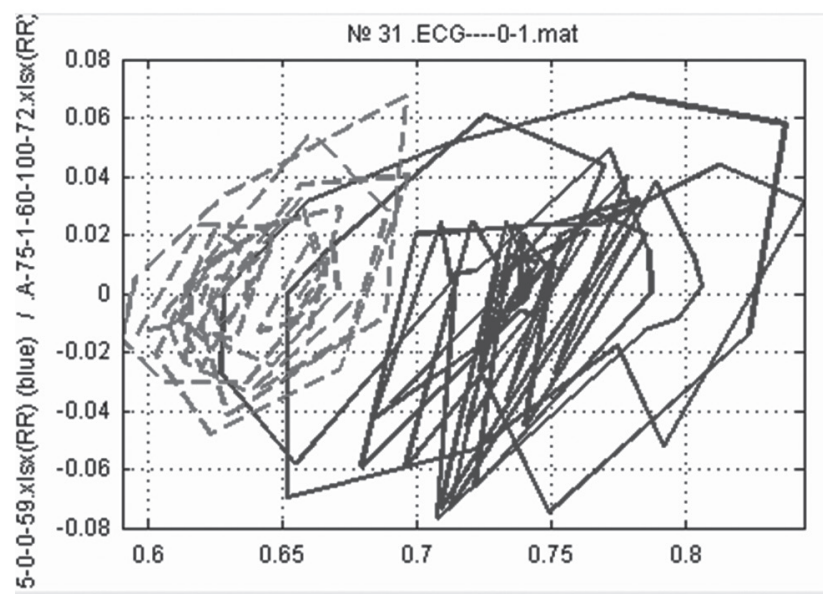

Рис. 5. Хаосограма юнака Р., 18 років (притаманна для усієї досліджуваної вибірки), отримана за аналізом інтервалів RR EKГ, зареєстрованої до (суцільна лінія) та під час (переривчаста лінія) компресії плеча

миттєва частота та фаза є чутливим динамічним індикатором мозкових регуляторних процесів. Використані методи аналізу не є загальноприйнятими у кардіології і потребують більш глибокого анатомо-фізіологічного вивчення та обгрунтування.

Нами проведено порівняльний аналіз динаміки часових та спектральних частотних показників інтервалів RR, PP та TT (табл. 2). 
Вивчення динаміки показників часового (HVRindex, VPR та VR та спектрального (VLF, LF, HF, TP) аналізу інтервалів RR, PP та TT електрокардіосигналу до та під час компресії плеча засвідчило наступне. Зареєстровано зниження показників часового аналізу. При цьому достовірні зміни на компресію спостерігались в інтервалах RR та PP. B інтервалі ТT достовірність була притаманна лише триангулярному індексу.

Динаміки показника VPR при адаптації на компресію плеча в ТT інтервалі мала найбільший розкид. Показники спектрального аналізу достовірно змінювались в усіх (RR, PP, TT) інтервалах. Вважаємо, більш поглиблене вивчення динаміки окремих інтервалів ЕКГ може бути в подальшому використане для вивчення та оцінки адаптаційної здатності окремих ділянок міокарда до компресії плеча чи інших впливів.

Геометричний метод аналізу показників ВСР. 3 метою візуалізації аналізу ВСР і оцінки отриманих показників використано геометричний метод, а саме - побудову двомірної скатерограми та хаосограми.

Скатерографія - кореляційна ритмографія. Для прикладу використано скатерограму юнака Р., 18 років, притаманну для усієї досліджуваної вибірки (рис. 4), зареєстровану до та під час компресії плеча манжетою.

Як бачимо з рис. 4, до вимірювання артеріального тиску «хмаринка» не симетрична, з нечіткими контурами зовнішніх країв, численними відсівами. Під час вимірювання артеріального тиску під впливом компресії манжетки «хмаринка» стала більш оформленою, скупченою, без численних відсівів, зміщена більш вліво по відношенню до вихідної. Отримані дані вказують на активацію симпатичної ланки ВНС під час вимірювання артеріального тиску.

Хаосограма - призначена для аналізу нелінійних «хаотичних» коливань. При оцінкі хаосограми даного обстеженого (рис. 5) отримаємо аналогічні результати. Зміщення хаосограми вліво та ії концентрація вказують на активацію симпатичної ланки ВНС під час вимірювання артеріального тиску.

Висновки. 1. Компресія плеча під час вимірювання артеріального тиску сприймається організмом як навантаження.

2. Адаптація організму до компресії плеча у молодих людей (18-20 років) супроводжується підвищенням активності периферійного (автономного), вегетативного, гіпоталамо-гіпофізарного рівнів регуляції діяльності серцево-судинної системи. Активність центральної нервової системи при цьому не зростає.

3. Продовження досліджень із застосуванням часового та спектрального аналізу ЕКГ в різних інтервалах дасть можливість в подальшому використовувати отриману інформацію для вивчення адаптаційної здатності окремих ділянок міокарду під час компресії плеча та під впливом інших факторів.

\section{Література.}

1. Баевский Р. М. Оценка адаптационных возможностей организма и риск развития заболеваний / Р. М. Баевский, А. П. Берсенева. - М. : Медицина, 1997. - 265 с.

2. Вакуленко Д. В. Інформаційна система морфологічного, часового, частотного та кореляційного аналізу артеріальних осцилограм у фізичній реабілітації : монографія / Д. В. Вакуленко. - Тернопіль : ТДМУ, 2015. - 212 с.

3. Смирнов К. Ю. Разработка и исследование методов математического моделирования и анализа биоэлектрических сигналов / К. Ю. Смирнов, Ю. А. Смирнов. - Санкт-Петербург : Научно-исследовательская лаборатория «ДИНАМИКА», 2001. - 60 с. 4. Heart rate variability. Standards of measurement, physioligical interpretation and clinical use. Task Force of the European Society of Cardiology and the North American Society of Pacing and Electrophysiology // Circulation. 1996. - Vol. 93, No. 5. - P. 1043-1065.

\section{References.}

1. Baevskii, R. M., Berseneva, A. P. (1997). Otsenka adaptatsionnykh vozmozhnostei organizma i risk razvitiya zabolevanii [Evaluation of adaptive capabilities of the organism, and the risk of diseases]. Moscow: Medicine [In Russian].

2. Vakulenko, D. V. (2015). Informatsiina sistema morfologichnogo, chasovogo, chastotnogo ta korelyatsiinogo analizu arterial'nikh ostsilogram u fizichnii reabilitatsiï [Information system of morphological, time, frequency and correlation analysis of arterial waveforms in physical rehabilitation]: a monograph. Ternopil': TDMU [In Ukrainian].

3. Smirnov, K. Yu., Smirnov, Yu. A. (2001). Razrabotka i issledovanie metodov matematicheskogo modelirovaniya I analiza bioelektricheskikh signalov [Development and research of methods of mathematical modeling and analysis of bioelectric signals]. Sankt-Peterburg: Research laboratory «DINAMIKA» [In Russian].

4. Heart rate variability. Standards of measurement, physioligical interpretation and clinical use. Task Force of the European Society of Cardiology and the North American Society of Pacing and Electrophysiology. (1996). Circulation, 93(5), 1043-1065. 